\title{
Mudanças Climáticas e os Refugiados do Clima como uma Questão de Segurança Humana: \\ Repensando a Proteção dos Direitos Humanos e o Multilateralismo no Século 21
}

\section{Diego Emanuel Arruda Sanchez}

Doutorando em Direito pela PUC-PR e Membro do Grupo de Pesquisa Meio Ambiente: Sociedades Tradicionais e Sociedade Hegemônica (PUCPR); Analista Ambiental do IBAMA/PR, Mestre em Ecologia e Especialista em Direito Tributário e do Trabalho; Bacharel em Ciências Biológicas (UFPR) e em Direito (UFPR). http://lattes.cnpq.br/0784308878183692.

https://orcid.org/0000-0003-2246-8459. sanchezadvcuritiba@gmail.com

As mudanças climáticas já vêm apresentando consequências nocivas sobre diversas dimensões da vida humana. Com robustas previsões e múltiplos estudos que já apontam para diversos efeitos severos e persistentes sobre diferentes aspectos da vida humana em sociedade, riscos estes que vão de impactos sobre as fontes de geração de energia a questões envolvendo segurança alimentar, aos problemas sociais e de saúde que o deslocamento forçado causado por ela também provoca. Estima-se que, até o ano de 2050, algo em torno de 150 a 250 milhões de pessoas serão obrigadas a deixar os seus lares, comunidades e os seus próprios territórios nacionais por conta das secas, desertificação, aumento do nível dos mares, perdas de lavouras, eventos climáticos extremos e outros efeitos adversos das mudanças climáticas. Trata-se, portanto, de uma anunciada crise de segurança humana e das relações internacionais sem precedente na história humana. Diante disto, este artigo tem por objetivo traçar um breve panorama sobre as complexas interconexões deste tema e realizar uma análise histórico-crítica do atual estágio de tutela protetiva desta população deslocada e as instituições de direito atualmente existentes que possam ampará-la e assegurar a proteção da sua dignidade humana. Este é um estudo realizado sobretudo sob a ótica do materialismo histórico e da teoria da sociedade de risco, e que busca analisar, em especial, o papel da ONU e seus órgãos, nas negociações do clima e no multilateralismo internacional nesta área temática do Direito e da política internacional como elementos indispensáveis para a manutenção da paz mundial.

Palavras-chave: Mudanças climáticas. Refugiados ambientais. Refugiados climáticos. Multilateralismo. Paz mundial. ONU.

CLIMATE CHANGE AND REFUGEES CLIMATE AS A HUMAN SECURITY ISSUE: RETHINKING THE PROTECTION OF HUMAN RIGHTS AND MULTILATERALISM IN THE 21ST CENTURY

Climate Change has already had harmful consequences on various dimensions of human life. With robust predictions and several studies that already point to several severe and persistent effects on various aspects of human life in society, these risks range from impacts on energy sources to issues involving food security to social and health problems that displacement. forced caused by it also causes. By the year 2050, an estimated 150 to 250 million people will be forced to leave their homes, communities and their own national territories because of droughts, desertification, rising sea levels, losses. crops, extreme weather events and other adverse effects of climate change. It is, therefore, an announced crisis of human security and of international relations unprecedented in human history. Given this, this paper aims to draw a brief overview of the complex interconnections of this theme and to perform a historical-critical analysis of the current stage of protective protection of this displaced population and the existing institutions of law that can support them and ensure the protection of human dignity, a study conducted mainly from the perspective of Historical Materialism and Risk Society Theory, which seeks to analyze, in particular, the role of the UN and its organs, climate negotiations and international multilateralism in this thematic area of the law and international policy as indispensable elements for the maintenance of world peace.

Keywords: Climate changes. Environmental refugees. Climate refugees. Multilateralism. World Peace. ONU. SUMÁRIO

1 Introdução. 2 Conectando mudanças climáticas, multilateralismo e a proteção internacional dos direitos humanos. 2.1 Os refugiados do clima, a governança ambiental e a proteção internacional dos direitos humanos. 2.2 A ONU, o SIPDH e a questão dos refugiados do clima. 2.30 desenvolvimento sustentável, o multilateralismo e a proteção internacional dos direitos humanos. 3 Conclusões. 4 Referências. 


\section{Humanos e \\ Democracia}

\section{INTRODUÇÃO}

No final de 2018 comemoramos os 70 anos da proclamação da Declaração Universal dos Direitos Humanos, marco jurídico que tem como propósito maior a garantia da manutenção da paz e da segurança internacional e que tem como valores supremos elencados no seu texto o respeito e a afirmação dos direitos humanos e da dignidade humana, documento, portanto, que após os horrores experimentados pela humanidade na Primeira e na Segunda Guerra Mundial, fundamental na construção de uma nova comunidade internacional que fosse capaz de impedir os Estados de voltarem a cometer os mesmos erros do século 20.

Ao mesmo tempo, contudo, que comemoramos estes 70 anos de notáveis avanços no âmbito da proteção dos direitos humanos e uma forte tendência de globalização da política mundial (BAYLIS; SMITH; OWENS, 2017), vivemos uma época marcada por uma convergência de graves crises de proporções e potencial destrutivo/transformador poucas vezes antes visto na História da humanidade (CRUTZEN, 2002, 2006; STEFFEN et al., 2011). Uma época marcada, sobretudo, pelo inédito e abrangente impacto das atividades humanas sobre o planeta, os seus ecossistemas, os seus ciclos naturais e as suas espécies; uma sociedade global, industrial, cientificista e pós-tradicional caracterizada pela existência e necessidade de instalação de mecanismos internos para o constante manejo e superação dos constantemente criados novos riscos desta sociedade da modernidade tardia (BECK, 2010; GIDDENS, 2010), na qual já há um elevadíssimo consenso de que são as mudanças climáticas que têm como causa as ações do homem sobre a natureza (IPCC, 2014b, p. 5); na qual há consenso da comunidade científica e política internacional sobre a importância estratégica dos objetivos de desenvolvimento sustentável e das medidas de mitigação e adaptação diante dos efeitos adversos das mudanças climáticas, tanto para a manutenção da paz mundial quanto para o futuro econômico e socioambiental das diversas nações; ciência, portanto, por parte de grande parte de um significativo conjunto de tomadores de decisão do cenário político global quanto ao fato de que atualmente as mudanças climáticas constituem-se em uma das questões mais dramáticas da política interna e externa de várias nações e sem dúvida o maior desafio com que a comunidade política internacional já precisou lidar em termos de proteção da dignidade humana e dos direitos humanos desde a Segunda Guerra Mundial.

Hoje, as mudanças climáticas configuram uma séria ameaça à segurança e saúde alimentar para diversos povos e regiões ao redor do globo (MCLEAN; TSYBAN, 2001; REUVENY, 2007). Um fenômeno global que já tem graves e num futuro próximo terá ainda maiores consequências sobre a renda, o modo de vida, a saúde, o acesso a recursos naturais e aos meios de subsistência de muitas populações em todo o planeta (BARNETT; ADGER, 2007; MCLEAN; TSYBAN, 2001; REUVENY, 2007; SCHEFFRAN; BATTAGLINI, 2011; WARNER et al., 2010), o que terá impactos socioambientais significativamente mais severos para os países menos desenvolvidos e para as populações mais vulneráveis destes e de outros países do planeta ( $c f$. IPCC, 2001, 2007; HUMPHREYS et al., 2010; BOYD, 2018). Por conta disto, a transformação dos compromissos internacionais diante das mudanças climáticas em ações concretas e em efetivas políticas públicas por parte de todos os Estados-Nação modernos tem se tornado um tema da mais elevada importância e urgência no âmbito do Direito, da economia e da política 
internacional (cf. CQNUMC, 1997; DINCER, I., 2000; HOFFERT et al., 2002; MARTIONOT, 2006; GIDDENS, 2010; DAHLMAN, 2007; BILGEN et al., 2008; BILEN. et al., 2008; FOX-PENNER et al., 2010; ARENT et al., 2011; BULKELEY et al. 2013; IPCC, 2014a; IPCC, 2014b; CQNUMC, 2015).

Aliado a isto e à crescente consciência da crise ambiental global, a segunda década do século 21 tem sido marcada por uma grande instabilidade e baixo crescimento da economia mundial e por uma série de graves conflitos na área macroeconômica (crise financeira global de 2008-2009, seguida pela crise da austeridade fiscal da Europa de 2010-2012 e crise global dos preços das commodities de 2014-2016) apenas começam a dar sinais de uma recuperação da saúde das suas economias (ONU, 2018; UNCTAD, 2017). Um início de recuperação da economia global a qual, contudo, infelizmente ainda é muito desigualmente distribuída entre os diversos países (UNCTAD, 2017).

Assim, dois séculos após o fim das Guerras Napoleônicas e de os principais Estados presentes no Congresso de Viena, em 1815, concordarem que a sociedade internacional não mais deveria ser deixada ao sabor de mecanismos de ajustamento da balança de poder; um pouco mais de 70 anos também após os governos aliados afirmarem na Declaração das Nações Unidas, de 1942, de que a vitória dos países aliados foi "essencial para defender a vida, a liberdade e a justiça", e sete décadas também após o surgimento de um regime de Direito Internacional que tem contribuído para a redução da probabilidade de guerras e de violações dos direitos das pessoas em larga escala; apesar de todos os avanços alcançados nas últimas décadas na seara dos direitos humanos, das negociações multilaterais e dos mecanismos internacionais pacíficos de resolução de conflitos, paradoxalmente vivemos atualmente, no Brasil e no mundo, um dos piores cenários na política internacional desde o afloramento da Segunda Guerra Mundial.

Então como evitar que esta fase de longa e profunda crise econômica destrua as conquistas humanitárias alcançadas ao longo desse período de moderada paz mundial compreendido entre o final da Segunda Guerra Mundial até os dias atuais? Como assegurar que as quase centenárias e mundialmente reconhecidas deficiências do sistema ONU não comprometam seriamente o multilateralismo, a cooperação internacional e os objetivos do Sistema Internacional de Proteção dos Direitos Humanos (SIPDH)? Como fazer com que a falta de compromisso de algumas das potências mundiais com o multilateralismo e os mecanismos pacíficos de solução de conflitos não venham a se tornar um estopim para uma ampla deterioração mundial dos direitos humanos e talvez para uma terceira Grande Guerra?

Estas mesmas dúvidas, em termos gerais, foram questões centrais que guiaram o pensamento de autores como Norberto Bobbio ao longo de muitas das suas obras. Em uma meIhor síntese desta preocupação, em seu livro "O terceiro ausente: ensaios e discursos sobre a paz e a guerra" Bobbio sintetiza estas mesmas preocupações gerais na seguinte questão "É possível, e como é possível, sair do sistema de equilíbrio pelo qual a paz sempre foi, e sempre será, uma trégua entre duas guerras, e aperfeiçoar o processo de democratização da comunidade internacional, cujo objetivo deveria ser aquele, próprio a todo sistema democrático, de estabelecer regras e instituir poderes para a resolução pacífica dos conflitos entre as partes?" (BOBBIO, 2009). Uma centenária preocupação do direito que agora, com a poluição, o aque- 


\section{Humanos e \\ Democracia}

cimento global e diversas outras dimensões da crise socioambiental moderna, têm, na interconexão entre direitos humanos e meio ambiente, nos mostrado um dos seus mais urgentes e dramáticos contornos.

Atualmente, se olharmos para esta ameaça aos direitos humanos e à paz mundial derivada da degradação do meio ambiente com a visão de pensadores como Ulrich Beck e Antony Giddens, veremos que se trata do resultado de um conjunto muito maior de crises da modernidade tardia (BECK, 2010; GIDDENS, 2010); ponto em que se observa que os maiores riscos à segurança humana neste início de novo século, ao contrário da segunda metade do século anterior, passou a ter como fonte causadora primordial problemas oriundos de alguma das muitas dimensões desta crise ambiental global (BARNETT, 2009; BARNETT; ADGER, 2007; HARTMANN, 2010; MATTHEW, 2018; REUVENY, 2007; SCHEFFRAN; BATTAGLINI, 2011). Um quadro em que a crise ambiental, as mudanças climáticas e a questão dos refugiados do clima passaram a ocupar, nas últimas décadas, um lugar de relevante destaque no interior dos debates de segurança humana e no qual a arena política global tem se mostrado cada vez mais atenta à interconexão existente entre a crise ambiental global e os objetivos internacionais de promoção do desenvolvimento, proteção da dignidade humana, cooperação entre os povos e manutenção da paz mundial.

Assim, considerando o fato de que esta convergência de crises constitui-se provavelmente em uma das maiores questões de segurança humana dos dias atuais (AMORIM, 2015), debate-se neste artigo a questão da proteção da dignidade humana dos refugiados do clima como elementos indispensáveis para a efetiva proteção da dignidade humana no século 21 . Analisa-se, a este respeito, no presente trabalho, em especial o papel da ONU e seus órgãos, nas negociações do clima e do multilateralismo internacional como arena política e instituições internacionais de fundamental importância para a manutenção da paz mundial.

\section{CONECTANDO MUDANÇAS CLIMÁTICAS, MULTILATERALISMO E A PROTEÇÃO INTERNACIONAL DOS DIREITOS HUMANOS}

As atividades humanas estão causando impactos crescentes sobre o meio ambiente em todas as escalas, interferindo de modo significativo e perigoso em quase todos os ecossistemas ao redor do mundo e de maneira grave em vários processos biogeoquímicos de escala global (CRUTZEN, 2002, 2006). Essa crise ambiental tem chegado a um ponto tal que a comunidade científica tem sistematicamente passado a reconhecer que a ação do homem sobre o planeta tornou-se um força geológica tão ampla, persistente e significativa que atualmente acredita-se que é justificável atribuir o termo "antropoceno", em vez de "holoceno", para a época geológica em que vivemos (CRUTZEN, 2002, 2006; STEFFEN et al., 2011; IPCC, 2014b).

Começamos, também, nas últimas décadas, a sentir as piores consequências da crise ambiental global e das mudanças climáticas, um período histórico em que, ao mesmo tempo, a sociedade científica já possui bastante consciência e certeza sobre a gravidade e extensão dos problemas atuais e futuros das mudanças climáticas (IPCC, 2014b, p. 5). Vivemos numa época em que, ao mesmo tempo em que já se conhece com bastante certeza a importância estratégica que esta emergência climática representa para vários aspectos da vida no planeta (STEFFEN, 2011), cada vez mais autores e instituições internacionais têm passado a compreender que a solução para o problema de se conciliar os imperativos da burocracia com as 
demandas da democracia é atualmente um dos maiores desafios dos governos modernos, os quais passaram a defender que a boa governança pública e a democracia não são apenas desejáveis, mas condições essenciais para o desenvolvimento de todas as sociedades (LEFTWICH, 1993; ADGER, 2003; BULKELEY, 2005; BULKELEY et al. 2013; SHIVA, 2016). Destacam ainda que, além da crise ambiental (BENJAMIN, 1998; GIDDENS, 2010; LEITE; SILVEIRA; BETTEGA, 2017), a crise democrática é também um dos maiores desafios jurídicos do século 21 (FLORINI, 2003; KARIN et al., 2010; MASON, 2012; CELIKATES, 2015).

Por essas razões, cada vez mais autores têm passado a defender os benefícios de se meIhorar os processos de environmental accountability como forma de aproximar as democracias modernas. Defendem também que o bom desenvolvimento das nações atualmente, em vários dos seus aspectos, depende em grande parte da capacidade que os Estados possuem de proteger a população e construir políticas públicas eficazes voltadas ao desenvolvimento sustentável (GLASBERGEN; BIERMANN; MOL, 2007). As múltiplas e graves conexões existentes entre mudanças climáticas e deslocamento forçado também já têm sido muito bem constatadas, previstas e examinadas por diversos outros autores, tais como Bates (2002), Bell (2004), Giddens (2010) e Matthew (2018), destacando que, paradoxalmente, muito pouco ou quase nada esses países têm se mostrado preparados para lidar com os 150 a 250 milhões de pessoas que se estima sejam obrigadas a deixar os seus lares, comunidades e os seus próprios territórios nacionais por conta das secas, desertificação, aumento do nível dos mares, perdas de lavouras, eventos climáticos extremos e outros efeitos adversos das mudanças climáticas até o ano de 2050 (MYERS, 2002).

Vivemos, portanto, uma época em que já se tem uma boa compreensão dos impactos futuros que as mudanças climáticas terão para vários aspectos da vida humana em nosso planeta; uma época em que já se conhece os atuais e muito bem se estima os seus impactos futuros para a saúde, bem-estar e diversos outros aspectos importantes para o futuro dos Estados, entre eles: segurança energética, mercados de carbono, políticas verdes, governança, mudança tecnológica e impostos, adaptação e geopolítica (DINCER, 1999; DINCER, 2000; ISSAR; ZOHAR; 2007; ROCKSTRÖM et al., 2009; GIDDENS, 2010; ARENT et al., 2011 ; BULKELEY et al.; 2013). Sabe-se também que as mudanças climáticas já são e num futuro próximo serão em escala ainda maior a grande causa motivadora dos deslocamentos forçados dos tempos atuais (IPCC , 2007; MYERS, 2002; WARNER et al., 2010, entre outros). E que, se nada for feito para interromper os atuais níveis de emissão de GEE, as consequências desta crise ambiental serão imensamente mais catastróficas para a economia e a manutenção da vida humana da forma como a conhecemos no nosso planeta (IPCC, 2014b; STERN, 2008; SCHEFFRAN; BATTAGLINI, 2011).

Em uma época também em que, apesar da significativa alteração dos ambientes constitucionais de vários Estados voltados ao aprimoramento da gestão ambiental em seus territórios ${ }^{1}$ (BOYD, 2018, p. 17-41), verifica-se também que as modificações do Direito e da gover-

\footnotetext{
Processo que, nas últimas décadas foi responsável pelo aumento substancial dos direitos procedimentais dos cidadãos em temas atrelados ao meio ambiente ao mesmo tempo em que contribuíram para a diminuição da pegada ecológica das nações, melhorando os índices dos indicadores ambientais destes países e transformou o ambiente político dos países de modo a torná-los mais prováveis a ratificarem compromissos ambientais internacionais ainda mais ambiciosos em mais de 80 países (BOYD, 2018, p. 17-41).
} 


\section{Democracia}

Humanos e

nança estatal da questão ambiental ocorridas no Direito Nacional e Internacional nas últimas décadas não têm se mostrado capazes de efetivamente interromper o aprofundamento da crise ambiental e prevenir as suas mais nefastas consequências. Constata-se que a anunciada crise humanitária global, resultado das mudanças climáticas, por todos estes motivos, será, sem sombra de dúvidas, no decorrer das próximas décadas, um tema de importância estratégica sobre diversos aspectos da vida humana e para o desenvolvimento de todos os países do planeta ao longo dos próximos anos. Algo que seguramente configurar-se-á, em pouco tempo, em uma das dimensões mais dramáticas das mudanças climáticas e o maior desafio humanitário dos últimos séculos.

\subsection{Os refugiados do clima, a governança ambiental e a proteção internacional dos direitos humanos}

Quando olhamos para este problema do risco que as mudanças climáticas representam para a segurança humana global, verifica-se que o modo como o Direito e a política, nacional e internacional, vem lidando com esta convergência de crises não tem se mostrado capaz de nem minimamente prevenir os seus impactos socioambientais mais adversos, ainda que o maior reconhecimento do direito ao meio ambiente saudável no cenário doméstico dos Estados-Nação por meio da incorporação deste valor nas sua Constituições tenha contribuído para a melhora da performance ambiental destes Estados. Entre outros benefícios, tem contribuído para um maior aumento do controle social (social accontability), em várias regiões ao redor do globo; para o fortalecimento da governança ambiental e melhora da instituição da legislação ambiental em âmbito constitucional e infraconstitucional nestes muitos países; para o aumento da frequência e importância no processo adjudicativo das decisões judiciais das Cortes nacionais (BOYD, 2018, p. 17-41).

$\mathrm{Na}$ visão de Humphreys et al. (2010, p. 1-33), a atual íntima relação existente entre as mudanças climáticas e os direitos humanos é algo muito claro e latente. Na sua visão, tal crise, tem por essência a característica de consistirem em ser uma interconexão de crises da economia, da política e do Direito Internacional, o que nos alertaria para a importância, ao tratarmos de temas atrelados aos impactos das mudanças climáticas, da utilização da linguagem e valores dos direitos humanos - haja vista a importância deste ramo do Direito para as situações nas quais os direitos não são reconhecidos, são indisponíveis ou fortemente contestados. Algo que faz destas questões onde há grande interconexão entre os direitos humanos e meio ambiente - em especial aquelas nas quais há impactos sobre as camadas mais vulneráveis da sociedade, comprometem ou demandam esforços de cooperação internacional, impactam os compromissos internacionais de redução das desigualdades e o futuro desenvolvimento das nações - em temas que o desenvolvimento sustentável tem passado a ser compreendido como uma grande linha condutora que, cada dia mais, passará a guiar o presente e o futuro da política e o direito internacional. Uma multicrise internacional para a qual, infelizmente, a forma como atualmente lidamos com o problema é, em diversos aspectos, problemática e muito pouco capaz de assegurar a proteção de diversas importantes dimensões dos direitos humanos de uma grande infinidade de indivíduos, sobretudo, das camadas mais vulneráveis da população global. 
Assim, embora a incorporação destes direitos fundamentais ao meio ambiente nas Cartas Constitucionais tenha sido algo que nas últimas décadas contribuiu enormemente para uma grande e rápida transformação da governança ambiental executada por estes Estados nos seus territórios ${ }^{2}$ e que, nos últimos anos, causou grandes transformações nos ambientes jurídicos e governança ambiental, principalmente em países como a Argentina, Portugal, Costa Rica, Brasil, Colômbia, África do Sul e Filipinas (BOYD, 2018, p. 28-41), trata-se de uma transformação que ainda precisa ocorrer no ordenamento jurídico de muitos outros países, posto que em grande parte de onde ela ocorreu representa um avanço carente de efetividade e em grande parte meramente simbólico e que, para o alcance de um mais concreto e efetivo resultado, na visão de Boyd seria muito beneficiada se fosse uma modificação que viesse também acompanhada de uma grande transformação no âmbito do Direito Internacional e da criação de uma ferramenta global de proteção (BOYD, 2018, p. 25-41).

Neste mesmo sentido, autores como Turner (2005), Humphreys et al. (2010), Boyle (2012), Weston e Bollier (2013), Daly e May (2018), também têm defendido que a forma tradicional de enfrentamento deste problema - baseada num direito privatista-liberal, no primado da soberania estatal e na governança individualizada do problema - não tem se mostrado suficientemente eficaz de superar esta grave crise da modernidade. Para eles, a melhor resposta a estas questões passa, em grande parte, pelo aumento do reconhecimento da crise ambiental como uma questão de direitos humanos. Na visão destes autores, o direito humano a um ambiente saudável seria uma valiosa forma de se complementar o regime de direito fundamental ao meio ambiente existente nos regimes constitucionais domésticos que floresceram nas últimas décadas ao redor do mundo. Um Direito Internacional que, no entendimento de Daly e May (2018), uniria as nações em volta de normas ambientais protetoras que reconheceriam, desta forma, a indivisível conexão existente entre os direitos humanos e o mundo natural que nos cerca.

Nesse aspecto Cullet (1995) destaca que, nos dias atuais, a preservação, conservação e restauração do meio ambiente são uma parte necessária e integrante do gozo, entre outros, dos direitos à saúde, à alimentação e à vida, incluindo uma qualidade de vida decente. Por outro lado, autores como Andrew Dobson e Melina Fachin também nos lembram que, infelizmente, o desafio de conciliar desenvolvimento sustentável e justiça social ainda é um paradoxo difícil de ser resolvido porque, ao mesmo tempo que são muitas das vezes - senão em todas - valores e realidades conflitantes, são também extremamente correlacionados e interdependentes (DOBSON, 1998; FACHIN, 2015).

Razão pela qual, para estes e outros autores, o reconhecimento do direito ao meio ambiente como uma questão de direitos humanos seria a melhor forma para o aprimoramento da governança global desta crise. Segundo eles, o meio ambiente saudável constituiria algo indispensável para a vida digna das presentes e futuras gerações, para o bom desenvolvimento de todas as sociedades e que os Estados têm o dever de elaborar políticas eficazes na busca

\footnotetext{
Algo que na visão de Boyd teria feito com que, em ao menos 80 países, nas últimas décadas, contribuísse enormemente para que o direito doméstico deste tenha passado a incorporar novos valores e princípios do desenvolvimento, a assegurar o direito ao acesso à informação como uma máxima no processo de governança ambiental, a propiciar maior participação pública nos processos de tomada de decisão e a melhor instrumentalizar ou fortalecer a questão da importância do acesso à justiça aos muitos afetados pelas externalidades ambientais (BOYD, 2018, p. 25-41).
} 
da sua proteção e promoção, um direito fundamental e indispensável que todo ser humano tem de acessar os bens, espaços e recursos naturais necessários para manter uma existência física e corporal (como comida, água e ar), mas também relacionado às coisas que os seres humanos precisam para ter uma vida psicológica e social saudável (como um grau ínfimo de interação e um nível mínimo de reconhecimento). Para estes, o direito humano ao ambiente saudável é uma precondição necessária para a promoção e gozo de vários direitos humanos globalmente reconhecidos (BAYLIS; SMITH; OWENS, 2017; CULLET, 1995; HISKES, 2008; HUMPHREYS et al., 2009; SACHS, 2004; SHRADER-FRECHETTE, 2006).

Nesse ponto vale a pena destacar ainda as conclusões do recente relatório do Conselho de Direitos Humanos da ONU, o qual enfaticamente destaca as obrigações e responsabilidades essenciais dos Estados e de outros responsáveis (incluindo empresas) e suas implicações nos acordos, políticas e ações relacionadas às mudanças climáticas.Adverte ainda, este documento, a toda a sociedade política global, que a busca pela coerência das políticas internacionais e os objetivos mundiais de mitigação e adaptação diante das mudanças climáticas levam-nos a fazer algumas importantes considerações a respeito da forma como as mudanças climáticas sempre foram tratadas no âmbito do Direito Internacional. Que a realidade atual da emergência global e o nível de compreensão que a comunidade internacional possui a respeito da interconexão existente entre mudanças climáticas e direitos humanos, impulsionam os Estados a um dever ético de agir de modo a atenuar as mudanças climáticas e impedir seus impactos negativos nos direitos humanos; a atuar de forma a garantir que todas as pessoas tenham a capacidade necessária para se adaptar às mudanças climáticas; a garantir a prestação de contas e remediar efetivamente os danos aos direitos humanos causados pelas mudanças climáticas; a mobilizar o máximo de recursos disponíveis para o desenvolvimento sustentável e baseado nos direitos humanos; a agir de forma cooperativa em âmbito internacional; a garantir a equidade na ação climática; a possibilitar que todos desfrutem dos benefícios da ciência e de suas aplicações; a proteger os direitos humanos de danos aos negócios; a assegurar o tratamento igual e não discriminatório em relação a estas políticas e aos riscos climáticos; a garantir uma participação significativa e informada a todos os seus cidadãos (OHCHR, 2019).

\subsection{A ONU, o sistema internacional de proteção dos direitos humanos e a questão dos refugiados do clima}

Após a Segunda Guerra Mundial, relevantes fatores contribuíram para que se fortalecesse o processo de internacionalização dos direitos humanos. A criação das Nações Unidas, com suas agências especializadas, constituiu o pilar do surgimento de uma nova ordem internacional, com preocupações que incluem a manutenção da paz e a segurança internacional, o desenvolvimento de relações amistosas entre os Estados, a admissão de um padrão internacional no plano econômico, social e cultural, a adoção de um padrão internacional de saúde, a proteção do meio ambiente, a criação de uma nova ordem econômica mundial e a proteção internacional dos direitos humanos (PIOVESAN, 2011).

Criada em 26 de junho de 1945, a Organização das Nações Unidas (ONU) foi estabelecida com seis órgãos principais (nenhum deles especificamente constituído para o enfrentamento dos problemas ambientais, considerando-se que naquela época, não se revelavam, nem de longe, uma das maiores preocupações para a temática da segurança humana), sendo 
eles: a Assembleia Geral, o Conselho de Segurança, o Conselho Econômico e Social, a Secretaria-Geral, o Conselho de Tutela e a Corte Internacional. Sucessora também da antiga Sociedade das Nações, neste processo a ONU recebeu, além da integralidade dos ativos de sua antecessora, as expectativas de uma sociedade internacional profundamente marcada e ainda atordoada pela ruptura totalitária ocorrida na Alemanha e na Itália e pelo fracasso da utopia da modernidade e da razão instrumental (AMORIM, 2015, p. 41).

Nos seus anos iniciais a ONU protagoniza a condução, tanto da formação e consolidação do sistema internacional de proteção da pessoa humana quanto do cuidado com o meio ambiente, sobretudo por meio da realização de grandes conferências diplomáticas sobre o tema e da codificação de seus principais temas em convenções multilaterais. Apenas mais tarde, entretanto, com a ascensão dos movimentos ambientalistas nos Estados Unidos e na Europa no final dos anos 60 - em grande parte impulsionados pela grave deterioração do meio ambiente causada pela falta de regulação das indústrias e atividades poluidoras nesses países, em resposta à crescente força do movimento ambientalista mundial, mas motivados também pelos debates e agenda política da descolonização - é que a questão ambiental, ao mesmo tempo que começa a extrapolar as paredes da Organização e ganhar também uma agenda regional, passa a receber maior destaque dentro da política internacional (AMORIM, 2015; IVANOVA, 2007).

Foi nesse contexto que, em 1968, a Assembleia Geral da ONU aprovou, em 3 de dezembro, a Resolução 2.398, na qual a Organização reconheceu que a relação entre o homem e o meio ambiente passava por profundas transformações, em razão dos avanços científicos e tecnológicos, e que os efeitos desses avanços poderiam trazer sérios riscos ao bem-estar social e à saúde física e mental do ser humano, bem como prejudicar o efetivo gozo de direitos humanos, tanto em países desenvolvidos quanto naqueles em desenvolvimento (AMORIM, 2015, p. 117). Ressalta-se também que, mais tarde, em 1972, na Conferência das Nações Unidas sobre o Meio Ambiente Humano, os 113 governantes reunidos em Estocolmo foram capazes de enfrentar coletivamente os desafios ambientais e criar o acordo que viria a se constituir na base da arquitetura internacional para abordar os problemas ambientais globais nas décadas subsequentes.

Foi apenas na década de 80 , contudo, que o problema da mudança climática finalmente deixou de ser uma questão em boa parte científica e passou a entrar na agenda dos formuladores de políticas ambientais. As advertências, cada vez mais coordenadas e unificadas, feitas por grupos de cientistas e, muitas vezes, reforçadas e retransmitidas para o políticos e opinião pública em geral por Organizações Não Governamentais ambientalistas, revelaram de que o conjunto das atividades humanas no planeta estariam provocando mudanças climáticas globais.

Este é um período em que o conjunto de Estados-Nação tem realmente se esforçado para a construção de uma eficaz política global de governança climática que seja capaz ao menos de mitigar ou adaptar os efeitos nocivos dessa nova realidade climática sobre a natureza, a saúde humana, a economia dos diversos países e a sociedade global como um todo. Processo este, no entanto, que não tem se mostrado suficientemente capaz de interromper o aumento das emissões globais de GEE e que embora tenha se baseado na lógica de impor sobre todos os atores internacionais, estatais e particulares, o dever de rever as estruturas 
mais básicas da economia moderna e repensar os pilares éticos que sempre sustentaram o desenvolvimento e as relações internacionais, não tem se mostrado uma abordagem suficientemente apta a promover mudanças capazes de interromper ou atenuar os piores impactos da emergência climática (VIOLA; FRANCHINI; RIBEIRO, 2013).

Um processo de evolução da economia global, do Direito Internacional e de busca de transformação das relações internacionais que é fruto de um esforço coletivo de diversos atores globais - e que teve, nas últimas décadas, como grandes marcos das suas conquistas a criação do Painel Intergovernamental sobre Mudanças Climáticas (IPCC), em 1988, voltado a fomentar, organizar, sintetizar e aprimorar o conhecimento científico então existente sobre o fenômeno das mudanças climáticas, o Protocolo de Kyoto, assinado na Rio-92, que entre outros compromissos definiu um calendário pelo qual os países-membros (principalmente os desenvolvidos) ficavam obrigados a cumprir uma meta de redução de emissão de Gases do Efeito Estufa (GEE) aos níveis de 1990 no período entre 2008 e 2012, e o Acordo de Paris, assinado em 2015, que similarmente teve por objetivo incentivar os diversos Estados a cumprirem uma meta predefinida de redução dos níveis de GEE, diferindo-se, entretanto, este novo Tratado em relação ao anterior, entre outros pontos também importantes, pelo fato de que as metas de redução, mesmo para os países desenvolvidos, não estarem desta vez definidas no próprio Tratado, mas terem ficarem a cargo dos próprios Estados-parte na forma das $\mathrm{Na-}$ tionally Determined Contributions (NDCs) e que tem, cada vez mais, levado os Estados e a comunidade política internacional a repensarem os limites da soberania Estatal, a reformularem a tradicional hegemonia conservadora das relações internacionais e a buscarem uma maior valorização do desenvolvimento sustentável como princípio norteador das relações internacionais.

Aliada a esta evolução do Direito e da política internacional relativa à emergência climática, tem crescido a preocupação de que as mudanças climáticas serão um dos maiores responsáveis pelos deslocamentos forçados ao longo do século 21 (IDMC, 2016; MYERS, 2002; UNHCR, 2009; WARNER et al., 2010). Algo que, quando entendido pelo prisma do compromisso internacional de busca do desenvolvimento, da paz mundial e da proteção da dignidade humana, impele-nos a procurar uma solução ampla e definitiva para a questão dos refugiados. A refletir a respeito da necessidade da criação de uma nova espécie de tutela protetiva sobre deslocados que agora abarcasse também, além dos seus critérios clássicos que ensejam a concessão de refúgio (a perseguição e ameaça à pessoa em razão da sua raça, religião, nacionalidade, pertencimento a um grupo social), aqueles que agora são obrigados a se deslocar por causa de eventos climáticos extremos ou da grave deterioração da qualidade ambiental da sua região de origem: a criação do instituto jurídico da tutela dos refugiados do clima.

Esta situação evidencia o risco que corremos de vivenciar em breve a maior crise de refugiados na história da humanidade (IPCC, 2007 ; MYERS, 2002; WARNER et al., 2010, entre outros) e revela-nos que as escolhas que fizermos nos próximos anos serão determinantes para o curso do progresso humano ao longo de todo o século 21. Que nos forçam, por conta disso, a repensar a estrutura básica da nossa sociedade e vários institutos clássicos do direito humano e do Sistema Internacional de Proteção dos Direitos Humanos (SIPDH), de forma a assegurar uma eficaz tutela protetiva à multidão de pessoas que serão gravemente afetadas pelas mudanças climáticas e seus eventos extremos. E a pensar que, no âmbito da segurança 
humana, da proteção internacional dos direitos humanos e do meio ambiente, não é mais tolerável que se continue a ignorar o grave impacto sobre a vida de 900 milhões de seres humanos que esta vertente da crise ambiental global vem ocasionando, levando-nos, cada vez mais, à certeza de que não podemos continuar ignorando os refugiados ambientais simplesmente porque não há modo institucionalizado de lidar com eles. Cenário que, conforme bem destaca Myers (2002), força-nos a expandir nossa abordagem aos refugiados em geral, a fim de incluir os refugiados ambientais em particular.

Este é um momento histórico no qual, como muito bem alertaram Ulrich Beck e Anthony Giddens, atesta-se a emergência da sociedade de risco por meio das ameaças ecológicas e que, inobstante a degradação ambiental tenha passado despercebida durante o processo de modernização, esta questão, em razão dos enormes riscos gerados, acentuou-se ao longo do último século. Um tempo também, conforme bem alertam o relatório do Alto Comissariado das Nações Unidas para os Refugiados (ACNUR, 2016) e os estudos de Myers (2002), entre outros, em que se verifica que a questão dos refugiados climáticos já se mostra um dos maiores desafios à preservação da paz mundial e um dos mais graves problemas humanitários do século 21.

\subsection{O desenvolvimento sustentável, o multilateralismo e a proteção internacional dos direitos humanos}

Como já vimos, já se tem bastante certeza científica sobre o fato de que as mudanças climáticas já vêm tendo, e terão ainda mais, complexos, profundos, graves e prolongados impactos sobre os ecossistemas, os ciclos naturais, o futuro de todas as formas de vida na Terra e sobre infinitas dimensões dos aspectos sociais, ambientais e econômicos da vida humanas (IPCC, 2001, 2007, 2014b). Estudos apontam também que, se nada for feito para se manter o aquecimento dentro do patamar máximo de $2^{\circ} \mathrm{C}$ acima dos níveis pré-industriais, as consequências das mudanças climáticas serão imensamente mais catastróficas para a economia e a manutenção da vida humana da forma como a conhecemos no nosso planeta (IPCC, 2014a; STERN, 2008; SCHEFFRAN; BATTAGLINI, 2011).

Já vivemos, infelizmente, em um mundo no qual milhões de pessoas, em grande parte do mundo, sobretudo na África e na Ásia, vêm sendo forçadas a deixar suas casas para buscar refúgio em outros lugares ou países. Já temos também o conhecimento de que, caso as previsões dos efeitos adversos do clima sobre o meio ambiente e o funcionamento dos ecossistemas se concretizem, num futuro breve (até 2050) teremos no mundo todo em torno de 150 a 250 milhões de refugiados climáticos, ou seja, de pessoas obrigadas a deixar os seus lares, comunidades e os seus próprios territórios nacionais por conta das secas, desertificação, aumento do nível dos mares, perdas de lavouras, eventos climáticos extremos e outros efeitos adversos das mudanças climáticas (MYERS, 2002).

Muito correto parece, portanto, o pensamento da política norueguesa e então primeira-ministra da Noruega, Gro Harlem Brundtland, a qual, na 44a sessão da Assembleia Geral das Nações Unidas, em 25 de setembro de 1989, em Nova York, proferiu um discurso que reflete bem o espírito dos pensadores mais progressistas da época. Segundo ela, a globalização econômica em escala sem precedentes que atualmente vivemos, a revolução na informação, a biotecnologia e outras tecnologias, a liberalização dos mercados de capitais e a consequente 


\section{Humanos e}

Democracia

integração dos movimentos comerciais e financeiros, trazem consigo um grande risco de que os Estados-Nação passem a perder o controle sobre importantes aspectos das relações internacionais e da segurança humana. Alertou então a primeira-ministra, neste seu seu discurso na Assembleia Geral, que se nada fosse feito, num futuro muito próximo os governos nacionais seriam cada vez menos capazes de lidar com uma situação de interdependência global (BRUNDTLAND, 2018).

Para a ministra Brundtland, estaríamos vivendo um período de transição e as escolhas que fizermos nestas décadas do início da transição seriam determinantes para o curso do progresso humano ao longo do novo milênio que ainda não havia se iniciado. Um período em que, segundo ela, por conta dos riscos oriundos da ameaça nuclear, da crescente degradação do meio ambiente, da necessidade de combater a pobreza e diminuir as desigualdades e os demais riscos da sociedade industrializada moderna, seria imprescindível que o conceito de segurança humana passasse a incorporar dentro de si, em ampla escala, o conceito de sustentabilidade. Para a ministra, havia chegado o momento de unir a humanidade na busca da solução pacífica e solidária desses problemas, de unir esforços na busca de soluções pacíficas e compartilhadas para os problemas oriundos da crise ambiental e das mudanças climáticas (BRUNDTLAND, 2018).

Defendeu ela também, naquela mesma ocasião, que havia chegado a hora de uma renovação do compromisso de todos os Estados-Nação ali presentes em busca dessas soluções; que as mudanças climáticas globais estavam emergindo como o problema ambiental mais alarmante que a humanidade já havia enfrentado; que seria de fundamental importância a criação de instrumentos efetivos para a governança global sobre a questão das mudanças climáticas; que a criação de um fundo internacional e os trabalhos desenvolvidos no âmbito do IPCC seriam de importância fundamental para o avanço das discussões e para o alcance de efetivos mecanismos de solução do problema e, sobretudo, que a governança coletiva da interdependência global não seria um slogan vazio, que estaríamos enfrentando uma era em que as novas ameaças à nossa segurança devem receber a mesma atenção de alto nível que as questões tradicionais relativas à guerra e à paz, que certos elementos de supranacionalidade deveriam agora ser considerados em âmbito global, sendo os desafios do meio ambiente um exemplo disso, e que havia chegado a hora de um novo compromisso com o multilateralismo para a busca de soluções globais (BRUNDTLAND, 2018).

Passados mais de 30 anos deste discurso da primeira-ministra norueguesa à frente das Nações Unidas, teriam as suas previsões se concretizado? Para que lado avançaram os riscos ambientais à segurança humana e para que lado caminhou, ao longo destes anos, o multilateralismo? Qual a compreensão atual do papel da dimensão ambiental sobre a questão da segurança humana global? Estariam as previsões da primeira-ministra, ao menos neste aspecto, corretas?

Quanto a este último ponto, como vimos anteriormente, atualmente há amplo consenso de que a degradação ambiental global, se não se caracteriza como a maior ameaça à segurança humana global da atualidade, ao menos certamente constitui-se em uma das principais preocupações para a efetiva garantia e manutenção desta última, um elemento-chave desta com interconexões fortes sobre todas as outras dimensões. Consenso este que além destes dados levantados, baseia-se e materializa-se também na presença de grande parte da essên- 
cia desta mesma conclusão em um grande número de importantes diplomas do Direito Internacional, de relatórios de diversos órgãos multilaterais, de relatórios de diferentes agências importantes de distintas potências mundiais, neles incluídos os comandos relativos a esta temática contidos na Declaração do Direito ao Desenvolvimento, de 1986, da Declaração do Rio, de 1992, e do Acordo de Paris, de 2015.

Entre estes, chama-nos especial atenção a presença de quase idêntico alerta a respeito da importância do aprimoramento da governança nacional e internacional do meio ambiente para o bom desenvolvimento dos povos e a manutenção da paz mundial, contido nas conclusões do Relatório de Brundtland, elaborado pela Comissão Mundial sobre o Meio Ambiente e o Desenvolvimento, no ano de 1987. Documento internacional este no qual, há mais de 30 anos, já se destacava que "formas insustentáveis de desenvolvimento empurram alguns Estados contra seus limites ambientais [...] e a competição pelo uso de recursos naturais comuns [...] pode fazer subir o nível dos conflitos internacionais e ameaçar a paz e a segurança internacionais".

De forma similar às conclusões do Relatório de Desenvolvimento Humano, de 1994, e também do relatório "A more secure world: our shared responsability" do Painel Sobre Ameaças, Desafios e Mudanças do Secretariado Geral da ONU, o qual apontou "a pobreza, doenças infecciosas e a degradação ambiental" como sendo as maiores ameaças atuais à paz mundial. Neste mesmo aspecto também versa o Relatório "Climate Change-Induced Water Stress and its Impacts on Natural and Managed Ecosystems", do Parlamento Europeu, do ano de 2008, assim como o Relatório "World in Transition - Climate Change as a Security Risk", do Conselho Consultivo sobre Mudanças Climática do governo alemão, publicado em 2007, e também a Estratégia de Segurança Nacional dos EUA, publicada em maio de 2010.

A este respeito, importante destacar os alertas de Anthony Giddens expressos em seu livro A Política das Mudanças Climáticas, no qual o autor, analisando em especial este cenário complexo e interdependente de crises oriundas das mudanças climáticas, alerta para os processos e interesses que promovem a divisão e envolvem interesses econômicos, socioambientais, geopolíticos e militares de grande peso. E, que por conta disto, as questões ligadas à mudança climática - especialmente se em conjunto com interesses da indústria de energia apesar de à primeira vista poder nos parecer um cenário que inexoravelmente nos guiará para um panorama de cooperação internacional, trata-se de um grave problema global que facilmente também pode enveredar para um aumento das hostilidades internacionais e um quadro de rápida deterioração da segurança humana mundial. Situação pessimista esta que, caso venha a ocorrer, ressalta o autor que as metas prioritárias de reduzir as emissões poluentes podem vir a se tornar vítimas de uma luta competitiva pelos recursos naturais, uma questão a exacerbar o quadro de tensões e divisões existente entre muitos dos Estados-Nações modernos (GIDDENS, 2010, p. 249-253).

Hoje é bastante seguro afirmar que a degradação ambiental global constitui uma grande ameaça à segurança humana. Um fenômeno de causa humana que se constitui em uma séria ameaça à segurança e saúde alimentar de milhares de pessoas, tendo também um grande potencial de se tornar uma criadora e impulsionadora de deslocamentos ambientais, além de um fenômeno que, ao que tudo indica, causará um considerável declínio econômico destas populações, além de grandes inundações de áreas costeiras e uma maior degradação da terra 
e dos recursos de água doce (BARNETT, 2009; BARNETT; ADGER, 2007; HARTMANN, 2010; MATTHEW, 2018; REUVENY, 2007; SCHEFFRAN; BATTAGLINI, 2011). Constata-se que estava bastante correta a preocupação destes vários autores aqui citados quanto aos prováveis impactos sobre os direitos humanos e a dignidade humana da presente e futuras gerações em uma escala global. Muito acertada e visionária também a previsão da primeira-ministra Brundtland quanto a este aspecto.

Acertada também a visão daqueles autores mais recentes, que vêm criticando o fato de que, por muitos anos, as negociações multilaterais e a instituição de políticas globais atreladas às mudanças climáticas estiveram muito centradas na lógica de construção de consenso e na adoção voluntária por parte dos Estados de políticas de mitigação e adaptação voltadas ao enfrentamento da questão, sem maiores meios coercitivos do Direito Internacional capazes de controlar a efetividade dos programas estatais ou de cobrar de cada Estado-Parte um maior compromisso ou uma maior efetividade das suas metas e programas. Compromissos internacionais que historicamente sempre ocorreram de forma independente e, em paralelo, à evolução legislativa e doutrinária e à sistemática protetiva do sistema internacional dos direitos humanos (HUMPHREYS, 2010, p. 4). Um processo em que, cada vez mais, a rígida e formal linguagem dos direitos humanos contrasta com a suave, dinâmica, pragmática e substantiva linguagem do regime jurídico internacional das negociações da Convenção-Quadro das Nações Unidas sobre Mudanças Climáticas (CQNUMC ou UNFCCC).

Nesse sentido, é algo que, como vimos anteriormente, tem levado vários autores a defender que a proteção internacional do meio ambiente, centrada em grande parte na cooperação voluntária dos países, no uso de instrumentos internacionais de natureza pouco vinculante (soft law), na aceitação voluntária do princípios do "desenvolvimento sustentável" e no não reconhecimento dos problemas ambientais como uma questão de direitos humanos propriamente dita, por si só não é uma abordagem capaz de assegurar bons níveis de qualidade ambiental (TURNER, 2005; HUMPHREYS, 2010, KNOX; PEJAN, 2018), entre outras obras e autores.

Faz-se necessário, na visão destes muitos autores, uma radical transformação na forma como atualmente o Direito Internacional lida com esta interconexão de crises, uma transformação político-normativa que, tal como a Comissão de Direitos Humanos da ONU tem sustentado, viesse a conferir uma holística e ampla visão de futuro e uma forma prática de se lidar com os problemas ambientais. Uma abordagem que, além fazer com que tais direitos fossem imediatamente reconhecidos e aplicados, imporia aos Estados e órgãos do sistema internacional de proteção dos direitos humanos o dever de aprimorarem, em âmbito global e regional, todo um conjunto de leis e procedimentos relacionados às tomadas de decisão ambientais. A defenderem também diversas vantagens que a abordagem dos direitos humanos para o enfrentamento das mudanças climáticas poderia vir a constituir uma mudança de paradigmas que na visão destes autores conectaria estas crises a uma visão mais holística, interdisciplinar e integrada do desenvolvimento e traria inúmeros benefícios recíprocos para estas duas áreas do Direito e da política internacional.

Em estágio ainda mais incipiente e pouco eficaz do que o próprio regime jurídico do clima, até muito recentemente, encontrava-se a situação específica da proteção dos direitos humanos das massas de deslocados derivadas desses eventos climáticos relacionados à emer- 
gência do clima. Ramo da política e do Direito Internacional que, ao contrário das tratativas voltadas à cooperação para a mitigação e adaptação em geral às mudanças climáticas que têm se desenvolvido no âmbito da CQNUMC, até recentemente encontrava-se totalmente carente de um maior amparo jurídico do Direito Internacional. Algo que só muito recentemente, com a entrada em vigor do Acordo de Paris, em 2015, e com a recente adoção em 2018 por mais de 160 países do Pacto Global para uma Migração Segura, Ordenada e Regular, começou a se alterar.

Um ramo do Direito Internacional, portanto, que até há bem pouco tempo muito avançou para o reconhecimento da vulnerabilidade destas grandes massas de afetados da emergência climática global e que, só muito recentemente, começou a dar sinais de mudança desta postura de grave omissão do sistema internacional de proteção dos direitos humanos. Destaca-se que, até então, à exceção de alguns casos particulares regionais de excepcional reconhecimento institucional em tratados regionais dessas espécies de refugiados, não possuía em nenhum diploma de maior poder coercitivo e escala global, um instrumento jurídico de força internacional que efetivamente assegurasse a esses deslocados do clima o formal reconhecimento da sua condição de refugiados. E que, mesmo com os avanços recentes, ainda não se pode dizer que nos dias atuais exista no conjunto de tratados, normas e diplomas, um ordenamento jurídico capaz de efetivamente assegurar a efetiva proteção desses migrantes e deslocados, o seu acolhimento e asilo, a eficaz tutela protetiva à sua vida e integridade física. Um ordenamento que efetivamente os proteja em escala global de violências estatais que possam agravar ainda mais a sua condição de afetados pelas mudanças climáticas, tal como atos abusivos de extradição coletiva e forçada ou atos discriminatórios que não lhes garantam, em seus locais de "asilo", os mesmos direitos e nível de proteção assegurados aos refugiados políticos em geral.

Neste aspecto é preciso alertar, portanto, que apesar da amplitude e seriedade do problema, a despeito dos dados alarmantes das previsões do número de pessoas que serão em um futuro próximo muito provavelmente afetadas de forma drástica pelos eventos extremos do clima e se tornarão refugiados ambientais e/ou climáticos, infelizmente, até o presente momento não existe um instrumento jurídico próprio que confira a esta espécie de deslocados forçados a concreta e categórica condição de refugiados. A bem da verdade, pouco existe, até o presente momento, uma clara definição do que realmente viria a ser um refugiado ambiental e/ou climático, não tendo, como talvez fosse desejável pela primeira-ministra Brundtland, a política e o Direito Internacional avançado o suficiente ainda neste aspecto das negociações multilaterais.

Constata-se, desse modo, que quanto a este ponto, a atual norma internacional fundamental para o reconhecimento e proteção dos refugiados - a Convenção de Genebra de 1951 - ainda não reconhece os refugiados ambientais e/ou climáticos como sendo verdadeiros refugiados, não conferindo a estes os mesmos direitos e tratamentos que o Direito Internacional atualmente obriga os Estados a conferirem aos demais refugiados. Não se sabe ao certo, também, como o Direito Internacional passará a interpretar esta norma em leitura conjunta com a redação do Pacto Global para uma Migração Segura, Ordenada e Regular que, apesar de ser um tratado e por essa razão um instrumento de pouco poder coercitivo, claramente busca assegurar aos deslocados ambientais o mesmo status protetivo assegurado às demais 


\section{Humanos e}

Democracia

classes de refugiados. Anomia no Direito Internacional que se revela, desta forma, um grande obstáculo à efetiva proteção da dignidade humana desta massa de deslocados. É uma falha protetiva que tem como ponto central da sua existência o fato de o termo "refugiado" utilizado na Convenção de Genebra, mesmo após a atualização efetivada pelo Protocolo de 1967, até os dias atuais, ainda se basear no seguinte conceito legal de refugiados:

"[...] qualquer pessoa que, temendo ser perseguida por motivos de raça, religião, nacionalidade, grupo social ou opiniões políticas, encontra-se fora do país de sua nacionalidade e que não pode ou, em virtude desse temor, não quer valer-se da proteção desse" (Protocolo de 1967, relativo ao Estatuto dos Refugiados, artigo 10, §1, alínea c).

Constata-se, portanto, como bem destacado por Rodrigues e Junior (2017), que da simples leitura da definição legal de refugiado anteriormente apresentada, o fato de trazer em si uma restrição conceitual que se mostra rigidamente apegada à noção de perseguição e grave ou iminente violação a direitos civis e políticos em seu país de origem, faz com que a norma não permita o reconhecimento dos refugiados ambientais e/ou climáticos como sendo verdadeiros refugiados. Não se enquadram, desse modo, ao menos no âmbito global do sistema ONU, os migrantes ambientais, uma classe de pessoas abarcadas pelo sistema tradicional de proteção internacional dos refugiados e protegidos pelo ordenamento típico da Convenção de 1951.

Algo bastante distinto, no entanto, ocorre no âmbito de alguns sistemas regionais de direitos humanos do mundo, em especial dos sistemas africano e americano, nos quais existem algumas iniciativas no sentido de ampliar o alcance normativo do conceito de refugiado, tais como a Convenção da Organização da Unidade Africana de 1969 (OUA) e a Declaração de Cartagena de 1984.

Desse modo, corretas, visionárias e muito necessárias de resgate e reafirmação as palavras da ministra Brundtland, que já nos anos 70 , bem antes do total florescimento e evidência dos problemas ambientais de escala global e das mudanças climáticas, proclamavam que o meio ambiente é "essencial para o bem-estar e para o gozo de direitos humanos fundamentais, até mesmo o direito à própria vida", e que todo o ser humano tem o direito fundamental à "liberdade, à igualdade e ao desfrute de condições de vida adequadas, em um meio ambiente de qualidade tal que lhe permita levar uma vida digna".

Uma visão de governança global para a resolução dos problemas ambientais e do aquecimento global que só viria a ser instituída muitos anos mais tarde, contendo também, neste discurso, uma visão de cooperação internacional para a questão do meio ambiente que, em grande parte, condiz com os princípios de Direito e compromissos multilaterais estabelecidos, por exemplo, na Declaração Sobre as Responsabilidades das Gerações Presentes em Relação às Gerações Futuras, adotada em 1997 pela Conferência Geral da Unesco, a qual estabeleceu que a fim de garantir que as gerações futuras se beneficiem das riquezas dos ecossistemas da Terra, "as gerações presentes devem juntar esforços em prol do desenvolvimento sustentável e preservar as condições de vida, particularmente a qualidade e a integridade do meio ambiente". Há também, na visão de multilateralismo e governança global contida na fala da primeira-ministra Gro Harlem, muita sincronia com os principais compromissos estabelecidos em diversas outras Convenções, Compromissos e Tratados Internacionais de Meio Ambiente, 
entre os quais aqueles presentes na Declaração do Rio, na Agenda 21, no Protocolo de Kyoto, na Convenção de Basileia, na Convenção de Cartagena, no Compromisso de Johannesburgo e no recém-celebrado Acordo de Paris.

Um discurso, que além de atento e bem consciente da gravidade e riscos oriundos da Modernidade Tardia e da Crise Ambiental da Modernidade Tardia, mostrou-se também muito bem sintonizado e ancorado em antigas proposições teóricas que se pautavam no utópico, mas universalmente desejável, objetivo de perpetuação da manutenção da paz, tais como o projeto kantiano de paz perpétua, ou as ideias do pacifismo jurídico de Hans Kelsen, Norberto Bobbio, entre outros. Algo que, lido neste contexto, mostra-se um conjunto de pensamentos que corre na mais perfeita sintonia com os princípios e objetivos, tanto da Declaração das Nações Unidas Sobre o Meio Ambiente Humano quanto da Declaração Universal dos Direitos Humanos, de 1948. Em perfeita harmonia também com os objetivos originais que levaram à criação da Organização das Nações Unidas, a qual, conforme termos do preâmbulo, artigos $1^{\circ}$ e $2^{\circ}$ do seu ato constitutivo (Carta da ONU), estabelece como um dos seus objetivos fundamentais o propósito de manter a paz e a segurança internacional por meio da adoção coletiva de medidas efetivas para se evitar ameaças à paz, ou a sua ruptura, reprimir atos de agressão, buscar a solução pacífica de controvérsias e fomentar a cooperação internacional para a solução dos problemas econômicos, sociais, culturais e humanitários da sociedade internacional e para promover e estimular o respeito aos direitos humanos e às liberdades fundamentais (AMORIM, 2015; ONU, 1948).

Evoluções estas dos instrumentos multilaterais de solução pacífica das controvérsias internacionais que, infelizmente, se examinarmos o atual cenário mundial, verificaremos que houve nos últimos anos, em grande parte pela política que vem sendo adotada pelo presidente Donald Trump de retirada dos Estados Unidos do Acordo de Paris, de fomento à economia do carvão e de endurecimento nas políticas migratórias norte-americanas, mas também pelo conjunto de crises econômicas observadas nos últimos anos, pelo surgimento e agravamento de várias crises de refugiados mundo afora, pela ascensão ou aumento da influência de setores ultraconservadores ou de extrema direita em vários lugares ao redor do mundo, que enfrentamos atualmente um momento muito delicado e de grandes riscos para a sobrevivência e avanço das ações humanitariamente progressistas do sistema ONU e das negociações multilaterais no âmbito das negociações do clima, algo que poderia vir a representar uma perda significativa do potencial destas negociações serem capazes de alcançar os almejados objetivos do Acordo de Paris.

Ascensão da direita e extrema direita que também tem causado grandes transformações no Brasil e América Latina e, nesta região, levado a um preocupante cenário de enfraquecimento das políticas e agendas ambientais e sociais progressistas. Uma mudança de rumos que segue o mesmo padrão do também observado em outros países onde, nestes últimos anos, houve ascensão de líderes de extrema direita e que, ao menos no âmbito regional da América Latina, se não causada, foi em grande parte impulsionada pelas recentes crises econômicas mundiais que contribuíram para o fim do superciclo das commodities iniciado no ano de 2003 (KUMANO, 2018), algo que, evidentemente, não foi a única causa mas que, aliado a outros fatores da política interna de cada um destes países, reascendeu e unificou forças conservadoras e neoliberais em boa parcela destes países. 


\section{Democracia}

Vem ocorrendo uma alternância do pêndulo político, que em termos regionais e globais tende a ser um complicador a mais para este cenário, ao menos em escala regional, posto que tem contribuído para um deslocamento do pêndulo esquerda-direita em muitos dos países da América Latina (FAGNANI, 2017; CARVALHO, GUERRA, 2016) e, ao menos no Brasil, contribuído para a ascensão de um governo de extrema-direita. Preocupante porque estes políticos e partidos de direita e/ou extrema-direita, no Brasil e no mundo, têm, em grande parte do seu conjunto de propostas e planos de governo, em geral, apresentado um discurso negacionista e/ou de forte resistência diante da questão das mudanças climáticas, favorável à economia do petróleo e um conjunto de propostas que em geral representam graves ameaça para a manutenção e promoção da proteção dos direitos humanos, políticos, civis e ambientais, no âmbito interno e externo, por parte desses países.

\section{CONCLUSÕES}

Conclui-se ao final deste trabalho que vivemos um tempo em que a questão dos refugiados climáticos mostra-se um dos maiores desafios à preservação da paz mundial e um dos mais graves problemas humanitários do século 21 . Constata-se que existem largas evidências científicas que apontam para inúmeros e graves impactos socioambientais em razão das mudanças climáticas. Impactos estes que repercutirão nos próximos anos de maneira grave sobre a vida de um grande número de pessoas no planeta, em especial sobre as populações de regiões mais sensíveis e sobre aquelas dos países pobres e/ou em desenvolvimento. Já no que se refere à migração humana, será um fenômeno que certamente fará com que ocorra, nas próximas décadas, um grande aumento do número de deslocamentos do clima em situação de grande vulnerabilidade.

Razão pela qual parece estar bastante correta a compreensão de Myers (2002) de que chegamos em um momento da nossa história de vida em sociedade em que se torna urgente a necessidade de ampliar e aprofundar nossa compreensão a respeito da crise de refugiados ambientais, estabelecendo as causas do problema - não apenas causas ambientais, mas também problemas associados, mais a interação dos dois conjuntos de forças. Um período em que a eficaz proteção dos direitos humanos e do meio ambiente mostram-se questões altamente conectadas e interdependentes, considerando que a eficaz proteção da dignidade humana nas próximas décadas parece depender fortemente do maior reconhecimento do direito humano ao meio ambiente saudável e da criação de um eficaz instrumento global de proteção deste direito.

Razão pela qual não se mostra justa ou aceitável que a definição atual de refugiados continue a se basear no arcaico e restrito conceito da Convenção de Genebra, não se mostrando coerente com os princípios do Direito Internacional e proclamados na DUDH, que o estatuto jurídico internacional de refúgio continue a não reconhecer aos refugiados climáticos a mesma esfera mínima de proteção que já é há muito tempo assegurada às outras classes de deslocados. Também não é tolerável que a atual anomia no Direito Internacional em relação à tutela protetiva dos deslocados do clima continue a constituir um empecilho para que os Estados e a sociedade global como um todo passem a atuar de forma mais coordenada, consciente e eficaz de modo a mitigar ou evitar as consequências mais severas desta grande crise 
de refugiados na história da humanidade. Este é um cenário que nos revela que as escolhas que fizermos nos próximos anos serão determinantes para o curso do progresso humano ao longo de todo o século 21.

Um cenário que nos força a repensar a estrutura básica da nossa sociedade e vários institutos clássicos do direito humano e do SIPDH de forma a assegurar uma eficaz tutela protetiva à multidão de pessoas que virão a se tornar gravemente afetadas pelas mudanças climáticas e seus eventos extremos. E leva-nos, invariavelmente, à conclusão de que não é mais tolerável que se continue a ignorar o forte impacto sobre a vida de milhões de pessoas simplesmente porque não há um modo institucionalizado de lidar com elas. A ter a certeza de que é preciso expandir a tutela protetiva do Direito Internacional assegurada aos refugiados no seu sentido clássico, de modo a incluir, no estatuto do Direito Internacional, também todas as distintas espécies de deslocados internacionais do clima.

Uma conjunção de crises e aproximação dos Direitos Humanos às questões de meio ambiente que leva-nos à conclusão de que, a despeito dos avanços regionais na tutela protetiva aos refugiados climáticos conferidas pelo advento da Convenção da Organização de Unidade Africana, de 1969, e apesar dos recentes avanços relativos à questão da proteção dos refugiados do clima presentes no Acordo de Paris, derivadas também do Pacto Global para uma Migração Segura, Ordenada e Regular, celebrado em 2018, até o presente momento nem o Direito Internacional nem o sistema internacional de proteção dos direitos humanos mostram-se como instituições e instrumentos capazes de efetivamente assegurar um bom nível de proteção da dignidade humana da grande massa de afetados pelas mudanças do clima. Existe a certeza, portanto, de que ainda vivemos um período de grande vulnerabilidade em termos de proteção dos direitos humanos mais básicos para gigantescas massas de indivíduos e um tempo de grande apreensão para os direitos humanos internacionais.

Uma evolução do Direito Internacional que se mostra urgente e fundamental, tanto para a preservação das boas relações internacionais entre os países quanto para evitar um infindável número de abusos sobre direitos humanos básicos de milhões de pessoas no presente momento e ainda mais ao longo de todo o curso deste longo e tortuoso século. Evoluções do Direito Internacional e dos instrumentos multilaterais de solução pacífica das controvérsias que, infelizmente, precisamos urgentemente agir de modo a evitar que a ascensão de setores ultraconservadores ou de extrema-direita em vários lugares ao redor do mundo continuem a dilapidar as suas bases. E que, para a sua sobrevivência e contínuo avanço protetivo, precisamos atentar para os riscos que a confluência desta crise com a dos interesses de certos setores conservadores da economia global, oferecem para a geopolítica global e continuidade do avanço dos objetivos e metas progressistas do sistema ONU e da política internacional. Ressalte-se que, se não forem criadas coalizões ou mecanismos de Direito para proteção ao retrocesso, isso pode vir a representar uma perda significativa do potencial destas negociações serem capazes de alcançar os almejados objetivos do Acordo de Paris.

\section{REFERÊNCIAS}

ACNUR. Alto Comissariado das Nações Unidas para os Refugiados. Tendências ACNUR. 2016. Disponível em: http://www.acnur.es/PDF/Tendencias2016.pdf. Acesso em: 13 dez. 2018.

ADGER, W. Neil et al. Governance for sustainability: towards a "thick" analysis of environmental decision making. Environment and planning A, v. 35, n. 6, p. 1.095-1.110, 2003. 
AMORIM, J. A. A. A ONU e o meio ambiente - direitos humanos, mudanças climáticas e segurança no século XXI. São Paulo: Atlas, 2015.

ARENT, D. J. et al. The status and prospects of renewable energy for combating global warming. Energy EconomiCS, v. 33, Issue 4, p. 584-593, jul. 2011.

BARNETT, J. The prize of peace (is eternal vigilance): A cautionary editorial essay on climate geopolitics. Climatic Change, v. 96, n. 1, p. 1-6, 2009.

BARNETT, J.; ADGER, W. N. Climate change, human security and violent conflict. Political Geography, v. 26, n. 26, p. 639-655, 2007. Disponível em: www.elsevier.com/locate/polgeo. Acesso em: 13 dez. 2018.

BATES, D. C. Environmental refugees? Classifying human migrations caused by environmental change. Population and Environment, v. 23, n. 5, p. 465-477, 2002.

BAYLIS, J.; SMITH, S.; OWENS, P. The globalization of world politics : an introduction to international relations. Oxford: Oxford University Press, 2017.

BECK, U. Sociedade de risco rumo a uma outra modernidade. 2. ed. São Paulo, SP: Editora 34, 2010.

BELL, D. R. Environmental refugees: what rights? which duties? Res Publica, v. 10, n. 2, p. 135-152, 2004.

BENJAMIN, A. H. V. A responsabilidade civil pelo dano ambiental no direito brasileiro e as lições do direito comparado. Brasília: Biblioteca Digital Jurídica do Superior Tribunal de Justiça, 1998.

BILEN, K. et al. Energy production, consumption, and environmental pollution for sustainable development: A case study in Turkey. Renewable and Sustainable Energy Reviews, v. 12, Issue 6, p. 1.529-1.561, ago. 2008.

BILGEN, S. et al. Global warming and renewable energy sources for sustainable development: A case study in Turkey. Renewable and Sustainable Energy Reviews, v. 12, Issue 2, p. 372-396, fev. 2008.

BOBBIO, N. O terceiro ausente : ensaios e discursos sobre a paz e a guerra. Organização Pietro Polito. Prefácio Celso Lafer. Barueri, SP: Ed. Manole, 2009.

BOYD, D. R. Catalyst for Change: evaluating forty years of experience in implementing the right to a health environment. In: KNOX, John H.; PEJAN, Ramin. The Human Right to a Healthy Environment. New York, NY: Cambridge University Press, 2018.

BOYLE, A. Human Rights and the Environment: Where Next? European Journal of International Law, v. 23, n. 3, p. 613-642, 2012.

BRUNDTLAND, G. H. For Global Cooperation on Environmental Problems. Population Council, v. 15, n. 4, p. 784787, 2018.

BULKELEY, H. et al. Governing Sustainability: Rio+20 and The Road Beyond, Environment and Planning C: Government and Policy 2013, v. 31, p. 958-970. DOI: 10.1068/c3106ed.

BULKELEY, H. Reconfiguring environmental governance: Towards a politics of scales and networks. Political Geography, v. 24, p. 875-902, 2005.

CARVALHO, Alba Maria P. de; GUERRA, E. C. Brasil no século XXI na geopolítica da crise: para onde apontam as utopias ? Revista de Políticas Públicas, v. 20, número especial, p. 267-280, 2016.

CELIKATES, R. et al. Transformations of Democracy: crisis, protest and legitimation. Maryland: Rowman \& Littlefield, 2015.

CQNUMC, ONU. Protocolo de Kyoto à Convenção-Quadro das Nações Unidas sobre Mudança do Clima. Disponível em: http://unfccc.int/resource/docs/convkp/kpeng.pdf. Acesso em: 20 maio 2019.

CRUTZEN, Paul J. Geology of mankind. Nature, v. 415, n. 6867, p. 23. 2002. DOI: https://doi.org/10.1038/415023a. CRUTZEN, Paul J. The antropocene: The current human-dominated geological era. Pontifical Academy of Sciences, n. Acta 18, p. 199-293, 2006. Disponível em: http://www.pas.va/content/dam/accademia/pdf/acta18/acta18-crutzen.pdf.

CULLET, Philippe. Definition of an Environmental Right in a Human Rights Context. Netherlands Quarterly of Human Rights, v. 13, n. 1, p. 25-40, 1995.

DALY, E.; MAY, J. R. Learning from Constitutional Environmental Rights. In: KNOX, John H.; PEJAN, Ramin. The Human Right to a Healthy Environment. Cambridge: Cambridge University Press, New York, NY. 2018.

DAHLMAN, C. Technology, globalization, and international competitiveness: Challenges for developing countries. In: Industrial Development for the 21st Century: Sustainable Development Perspectives. New York, 2007. Disponível em: http://www.un.org/esa/sustdev/publications/industrial_development/full_report.pdf. Acesso em: 21 maio 2019.

DINCER, Ibrahim. Environmental impacts of energy. Energy policy, v. 27, n. 14, p. 845-854, 1999. DOI: 1999.10.1016/S0301-4215(99)00068-3. 
DINCER, I. Renewable energy and sustainable development: a crucial review. Renewable and Sustainable Energy Reviews, v. 4, Issue 2, p. 157-175, jun. 2000. DOI: 10.1016/S1364-0321(99)00011-8.

DOBSON, A. Justice and the environment: Conceptions of environmental sustainability and theories of distributive justice. Oxford: Clarendon Press, 1998.

FACHIN, M. G. Direitos humanos e desenvolvimento. Rio de Janeiro: Ed. Renovar, 2015.

FAGNANI, E. O fim do breve ciclo da cidadania social no Brasil (1988-2015). Texto para Discussão, Unicamp, Instituto de Educação, v. 308, 2017.

FLORINI, A. The coming democracy: new rules for running a new world. Washington, D.C: Island Press, 2003.

FOX-PENNER et al. Smart Power: Climate Change, the Smart Grid, and the Future of electric utilities. 2. ed., 2010. ISBN-13: 978-1610915892.

GIDDENS, A. A política da mudança climática. Rio de Janeiro: Zahar, 2010. $314 \mathrm{p}$.

GLASBERGEN, P.; BIERMANN, F.; MOL, A. P. J. (ed.). Partnerships, governance and sustainable development: Reflections on theory and practice. Cheltenham, Reino Unido: Edward Elgar Publishing, 2007.

HARTMANN, B. Rethinking climate refugees and climate conflict: Rhetoric, reality and the politics of policy discourse. Journal of International Development, Nova Jersey, EUA: John Wiley \& Sons, v. 22, n. 2, p. 233-246, 2010. Disponível em: http://doi.wiley.com/10.1002/jid.1676. Acesso em: 14 dez. 2018.

HISKES, R. P. The human right to a green future: Environmental rights and intergenerational justice. New York, NY: Cambridge University Press, v. 27, n. 4, p. 1-171, 2008. Disponível em: https://doi.org/10.1017/ CBO9780511575396.

HUMPHREYS, S. Introdution: human rights and climate change. In: HUMPHREYS, Stephen (Ed.). Human rights and climate change. Nova lorque: Cambridge University Press, 2010.

IDMC. Internal Displacement Monitoring Centre. IDMC Annual Report 2015. Geneva, Switzerland. 2016. Disponível em: http://www.internal-displacement.org/sites/default/files/publications/documents/201607-annual-report-2015-en.pdf. Acesso em: 3 dez. 2020.

IPCC. Climate Change 2001: Synthesis Report - A Report of Working Group I of the Intergovernmental Panel on Climate Change. Cambridge University Press, 2001.

IPCC. Climate Change 2007: Synthesis Report. Summary for Policymakers. Cambridge University Press, 2007. DOI: https://doi.org/10.1136/bmj.39420.654583.25.

IPCC. Climate Change 2014: Synthesis Report. Contribution of Working Groups I, II and III to the Fifth Assessment Report of the Intergovernmental Panel on Climate Change [Core Writing Team, R.K. Pachauri and L.A. Meyer (eds.)]. IPCC, Geneva, Switzerland, 2014a. 151 p. Disponível em: http://www.ipcc.ch/pdf/assessment-report/ ar5/syr/AR5_SYR_FINAL_SPM.pdf.

IPCC. Climate Change 2014. Mitigation of Climate Change. Contribution of Working Group III to the Fifth Assessment Report of the Intergovernmental Panel on Climate Change. Cambridge, UK, Nova lorque, USA: Cambridge University Press, 2014b.

ISSAR, A. S.; ZOHAR, M. Climate change: environment and history of the Near East. Berlin: Springer, 2007.

IVANOVA, M. Designing the United Nations Environment Programme: a story of compromise and confrontation. International Environmental Agreements: Politics, Law and Economics, Germany: Springer Netherlands, v. 7, n. 4, p. 337-361, 2007. Disponível em: http://link.springer.com/10.1007/s10784-007-9052-4. Acesso em: 15 dez. 2018.

KARIN, B. et al. (ed.). Environmental politics and deliberative democracy: Examining the promise of new modes of governance. Cheltenham, Reino Unido: Edward Elgar Publishing, 2010.

KNOX, J. H.; PEJAN, R. The Human Right to a Healthy Environment. New York, NY: Cambridge University Press, 2018.

KUMANO, M. Y. El ciclo electoral 2017-2019 en América Latina. bie3: Boletín I.E.E.E., Instituto Español de Estudios Estratégicos, n. 10, p. 624-640, 2018. ISSN-e 2530-125X. Disponível em: https://dialnet.unirioja.es/servlet/ articulo?codigo $=6555529$. Acesso em: 11 dez. 2018.

LEFTWICH, A. Governance, democracy and development in the Third World. Third World Quarterly, v. 14, n. 3, p. 605-624, 1993.

LEITE, J. R. M.; SILVEIRA, P. G.; BETTEGA, B. Princípios estruturantes do Estado de Direito para a Natureza. In: LEITE, J. R. M.; DINNEBIER, F. F. (org.). Estado de direito ecológico: conceito, conteúdo e novas dimensões para a proteção da Natureza. São Paulo: Instituto O Direito por um Planeta Verde, 2017. p. 166-201.

MASON, M. Environmental democracy: A contextual approach. Abingdon, Inglaterra, Reino Unido: Routledge, 2012. 
MATTHEW, R. A. Climate change adaptation and peacebuilding. In: SWAIN, A.; ÖJENDAL, J. Routledge Handbook of Environmental Conflict and Peacebuilding. Londres: Routledge, 2018. p. 108-120.

MCLEAN, R. F. et al. Coastal Zones and Marine Ecosystems. In: Climate Change 2001: Impacts, Adaptation, and Vulnerability. Contribution of Working Group II to the Third Assessment Report of the Intergovernmental Panel on Climate Change. Cambridge, Reino Unido: Cambridge University Press, 2001. p. 343-379.

MYERS, N. Environmental refugees: A growing phenomenon of the 21st century. Philosophical Transactions of the Royal Society B: Biological Sciences, v. 357, n. 1.420, p. 609-613, 2002.

OHCHR. United Nations High Commissioner for Human Rights. Key Messages on Human Rights and Climate Change. 2019. Disponível em: https://www.ohchr.org/Documents/Issues/ClimateChange/COP21.pdf\%0Ahttps://www.ohchr.org/Documents/Issues/ClimateChange/KeyMessages_on_HR_CC.pdf. Acesso em: 14 set. 2019. ONU. World Economic Situation and Prospects 2018. 2018.

ONU. Declaração Universal dos Direitos Humanos. Assembleia Geral das Nações Unidas: Paris/França, 1948.

PAINTER, D. S. The Cold War: an international history. The making of the contemporary world. Londres, Nova lorque: Routledge, 1999.

PIOVESAN, F. Direitos humanos e o direito constitucional internacional. 12. ed. São Paulo: Saraiva, 2011.

REUVENY, R. Climate change-induced migration and violent conflict. Political Geography, v. 26, n. 6, p. 656-673, 2007. Pergamon. Disponível em: https://www.sciencedirect.com/science/article/pii/S0962629807000601. Acesso em: 14 dez. 2018.

ROCKSTRÖM, J. et al. Planetary boundaries: Exploring the safe operating space for humanity. Ecol. Soc. 14, 32 (2009). Disponível em: http://www.ecologyandsociety.org/vol14/iss2/art32/.

RODRIGUES, V. M.; JUNIOR, A. L. Refugiados ambientais: da necessidade de proteção jurídica internacional. Revista do Programa de Pós-Graduação em Direito da UFC, v. 37, n. 1, p. 355-368, 2017.

SACHS, W. Environment and human rights. Development, v. 47, n. 1, p. 42-49, 2004. Disponível em: https://doi. org/10.1057/palgrave.development.1100016.

SCHEFFRAN, J.; BATTAGLINI, A. Climate and conflicts: The security risks of global warming. Regional Environmental Change, v. 11, n. SUPPL. 1, p. 27-39, 2011.

SHELTON, D. Human Rights and the Environment_what specific environmental rights have been recognized? Denv. J. Int'l L. \& Pol'y, v. 35, n. 1, p. 129-171, 2008.

SHIVA, V. Earth democracy: Justice, sustainability and peace. Londres: Zed Books, 2016.

SHRADER-FRECHETTE, K. Environmental Justice : Creating Equity, Reclaiming Democracy. Oxford: Oxford University Press, Incorporated, 2006.

STEFFEN, W. et al. The Anthropocene: conceptual and historical perspectives. Philosophical Transactions of the Royal Society of London A: Mathematical, Physical and Engineering Sciences, v. 369, n. 1.938, p. 842-867, 2011.

STERN, N. The economics of climate change. American Economic Review, v. 98, n. 2, p. 1-37, 2008.

TURNER, S. The Human Right to a Good Environment - The sword in the stone. Non-State Actors and International Law, v. 4, n. 3, p. 277-301, 2005. Disponível em: https://doi.org/10.1163/1571807042794663. Acesso em: 13 nov. 2019.

UNCTAD. United Nations Conference on Trade and Development. Trade and Development Report 2017. Current Trends And Challenges in The World Economy, 2017.

UNHCR. In Search of Shelter: Mapping the Effects of Climate Change on Human Migration and Displacement. 2009.

VIOLA, E.; FRANCHINI, M.; RIBEIRO, T. L. Sistema internacional de hegemonia conservadora: governança global e democracia na era da crise climática. São Paulo: Annablume, 2013.

WARNER, K. et al. Climate change, environmental degradation and migration. Natural Hazards, Springer Netherlands, v. 55, n. 3, p. 689-715, 2010. Disponível em: http://link.springer.com/10.1007/s11069-009-9419-7. Acesso em: 14 dez. 2018.

WESTON, B. H.; BOLLIER, D. Toward a recalibrated human right to a clean and healthy environment: making the conceptual transition. Journal of Human Rights and the Environment, v. 4, n. 2, p. 116-142, 2013. 